\title{
PAROCHIALISM AND PLURALISM IN CYBERSPACE REGULATION
}

\author{
ALLAN R. STEIN ${ }^{\dagger}$
}

I predicted a few years ago that the greater connectedness brought about by globalization in general, and technology in particular, would introduce a new humility into our jurisdictional attitudes. ${ }^{1}$ Jurisdictional and choice-of-law rules premised on hermetically sealed sovereignty, where governments had exclusive power over their citizens and territory, did not fit a world in which the power and influence of governments extended beyond their borders and collided with conflicting legal norms within their borders. Connectedness, I concluded, would inevitably produce a new sensitivity in conflict of laws to the multiple sources of power and authority with which people must contend in a wired world.

Professors Berman and Reidenberg, while sympathetic with that perspective, have here suggested an appropriate caveat: technology can both connect and separate, and globalization can turn governments both outward toward cooperation and inward toward isolation. Connectedness can make us xenophobic as well as cosmopolitan.

Thus, Professor Reidenberg discusses how technology enables states to exercise control over multistate electronic transactions in order to enforce their own, legitimate regulatory preferences. ${ }^{3} \mathrm{He}$ is generally sympathetic to such assertions of national authority and rejects the plea of "Internet separatists" for governments to leave cyberspace alone. ${ }^{4}$

\footnotetext{
${ }^{\dagger}$ Professor of Law, Rutgers University School of Law, Camden. I would like to thank Perry Dane, Rochelle Dreyfuss, Jay Feinman, Graeme Dinwoodie, Greg Lastowka, Dennis Patterson, and Linda Silberman for their valuable input.

${ }^{1}$ Allan R. Stein, Frontiers of Jurisdiction: From Isolation to Connectedness, 2001 U. CHI. LEGAL F. 373, 374 ("[T] he old jurisdictional clothes do not fit the new body politic, but we are not ready to donate them to Goodwill quite yet.”).

${ }^{2}$ See id. at 397 (predicting that technology and globalization will foreclose unilateral assertions of jurisdiction and lead to reciprocal, expansive assertions of authority between sovereigns). (2005).

${ }^{3}$ See Joel R. Reidenberg, Technology and Internet Jurisdiction, 153 U. PA. L. REV. 1951

${ }^{4}$ Id. at 1953 .
} 
Professor Berman, in contrast, finds the turn inward more troubling. He presents three "case studies" of "parochial" application of forum law by American courts that suggest a disturbing trend. ${ }^{5}$ I want to focus here principally on his essay. Professor Berman asserts that a "cosmopolitan" perspective would provide a better approach to multistate problems in an interconnected world. Such an approach, he suggests, should take account of the multiple communities with which people increasingly affiliate, not merely the interests of affected governments. ${ }^{6}$ This corresponds with Professor Berman's earlier advocacy of legal pluralism in cyberspace regulation, which called upon courts to take account of the fact that legal norms are not produced exclusively by governments, and other norm-generating communities increasingly defy territorial definition. ${ }^{7}$

Berman's cosmopolitanism melds two separate critiques into one: a parochialism critique which bemoans the knee-jerk tendency of courts to apply their own law without taking adequate account of the extraterritorial implications of their adjudication, sometimes without even recognizing the presence of a choice of law; ${ }^{8}$ and a pluralism critique which bemoans the tendency of courts to think about government-generated legal norms as the only available sources of applicable law. ${ }^{9}$

Professor Berman's parochialism critique is embraced at some level by most of the dominant approaches to conflict of laws, from Beale's vested rights theory to modern "substantivism." The core premise of virtually every conflicts theory is a distinction between jurisdiction and choice of law; just because a judge has authority to resolve a dispute

\footnotetext{
${ }^{5}$ Paul Schiff Berman, Towards a Cosmopolitan Vision of Conflict of Laws: Redefining Governmental Interests in a Global Era, 153 U. PA. L. REV 1819 (2005).

${ }^{6}$ See id. at 1859 (“Cosmopolitanism seeks 'flexible citizenship,' in which people are permitted to shift identities amid a plurality of possible affiliations and allegiances. These allegiances could also include nonterritorial communities, such as those found in Internet chat rooms." (footnote omitted)).

${ }^{7}$ See Paul Schiff Berman, The Globalization of Jurisdiction, 151 U. PA. L. REV. 311, 323 (2002) (explaining that the pluralist theory of jurisdiction acknowledges the involvement of nonstate communities in the creation of legal norms and the reshaping of existing legal regimes).

${ }^{8}$ See Berman, supra note 5, at 1823 ("[J] udges seem to assume that U.S. law should apply, even without any sustained discussion of other possible outcomes." (emphasis omitted)).

${ }^{9}$ See id. at 1862 ("[C] ourts should consider community affiliations that are not associated with nation-states, such as industry standards, norms of behavior promulgated by non-governmental organizations, community custom, and rules associated with particular activities, such as Internet usage.").
} 
does not mean that forum law necessarily provides the appropriate measure of the parties' rights. ${ }^{10}$ As acknowledged by Professor Berman, contemporary conflicts approaches already take into account the multiplicity of states affected by the parties' activities. ${ }^{11}$ Professor Berman attempts to distinguish his approach from both the "most significant relationship" focus of the Restatement (Second) of Conflict of Laws $^{12}$ as well as the "reasonableness" test of the Restatement (Third) of Foreign Relations Law by his openness to nonterritorial, non-stategenerated, legal norms:

Perhaps most importantly, because a focus on community affiliation may lead us to consider nonstate communities, a cosmopolitan framework is far more likely to allow a pluralist consideration of how norms generated outside of formal governmental channels may bind sub-, supra-, and transnational communities. ${ }^{13}$

Yet, as discussed below, ${ }^{14}$ this pluralistic perspective is doing no work in his case analysis. His case analysis focuses exclusively on the interest of affected states, not the interests of other nonterritorial communities. Drained of its pluralistic emphasis, "cosmopolitanism" seems little more than a plea to avoid parochial choices of law. Few, if any, conflicts scholars would take issue with Professor Berman's plea that courts at least recognize the existence of a choice of law. In this sense of wanting courts to be other-regarding, we are all, or mostly all, cosmopolitanists. He is surely right that courts must be increasingly attuned to the extraterritorial implications of their attempts to regulate global activity through adjudication.

Professor Berman's parochialism critique of Brainard Currie's "interest analysis" is particularly trenchant. It is myopic for courts to as-

${ }^{10}$ This is not to say that forum law is not significantly privileged under some approaches, particularly under the realist tradition of Walter Wheeler Cook and Brainard Currie. But even under those least "cosmopolitan" approaches, application of forum law was not considered an automatic consequence, but rather had to be reconciled with the substantive policies of forum law. If, because of some foreign elements, the forum's substantive policy would not be advanced, forum law was not automatically applied. See Perry Dane, Vested Rights, "Vestedness," and Choice of Law, 96 YALE L.J. 1191, 1196-1204 (1987) (examining the critiques of territorialism).

${ }_{11}^{11}$ Berman, supra note 5, at 1862-63 (discussing the Restatement (Second) of Conflicts).

${ }^{12} I d$. at 1862 ("It is unclear, however, whether [the 'most significant relationship' test of the Restatement] include[s] affiliations that are neither citizenship-based nor territory-based. In contrast, cosmopolitanism would acknowledge such additional affiliations.”). Professor Berman would also dispense with any presumptions concerning the appropriate choice of law in particular categories of cases. Id.

${ }^{13} I d$. at $1863-64$.

${ }^{14}$ See infra notes 18-22 and accompanying text. 
sume that the only interest of the forum state is having its own law applied for the benefit of its own citizens. States have a long-term interest in crafting and enforcing a coherent transnational legal order:

[F] rom a long-term geopolitical perspective, whether or not an individual citizen wins a lawsuit is actually of very little interest to a state. Instead, states may have an interest in being seen to comply with an agreed-upon international order. States benefit from a shared world system, with its interlocking set of reciprocal benefits and burdens. If a state is too parochial in pursuit of its short-term interests, it may damage its longer-term goals by creating a lack of trust in other states. ${ }^{15}$

Unlike Professor Berman, I do see evidence that courts are increasingly sensitive to this perspective. The evolution of the courts' personal jurisdiction doctrine in Internet-related disputes suggests that courts are coming to appreciate that excessive assertions of authority can unduly inhibit extraterritorial activity beyond the courts' legitimate regulatory authority. ${ }^{16}$

The more innovative, but less convincing, piece of Professor Berman's critique is his suggestion that courts need to be more otherregarding not only toward competing legal rules promulgated by governments, but toward norms of behavior generated by nongovernmental, nonterritorial communities:

Such a jurisprudence looks to a variety of possible legal sources. First, courts can consider the multiple domestic norms of nation-states affected by the dispute... Second, international treaties, agreements, or other statements of evolving international or transnational norms may provide relevant guidance. Third, courts should consider community affiliations that are not associated with nation-states, such as industry standards, norms of behavior promulgated by non-governmental organizations, community custom, and rules associated with particular activities, such as Internet usage.

This critique resonates with the seminal and controversial work by David Post and David Johnson advocating a hands-off approach to internet regulation in deference to the self-regulating norms generated by the community of Internet users. ${ }^{18}$ I have previously expressed

\footnotetext{
${ }^{15}$ Berman, supra note 5, at 1850.

${ }^{16}$ See Allan R. Stein, Personal Jurisdiction and the Internet: Seeing Due Process Through the Lens of Regulatory Precision, 98 NW. U. L. REV. 411, 444-46 (2004) (discussing the increasing reluctance of courts to assert personal jurisdiction on the basis of a defendant's Internet activity).

${ }_{18}^{17}$ Berman, supra note 5, at 1862.

18 See generally David R. Johnson \& David G. Post, The Rise of Law on the Global Network, in BORDERS IN CYBERSPACE: INFORMATION POLICY AND THE GLOBAL INFOR-
} 
skepticism that the universe of Internet users was a sufficiently coherent community to generate the kind of legal order to which states sometimes defer. $^{19}$ I am equally skeptical that courts could make sense out of treating litigants as "cosmopolitan patriots," ${ }^{, 20}$ with rights and obligations defined not merely by reference to the law of the governments with connections to their controversy, but by reference to their "multiple overlapping communities."

None of the parochialism that Professor Berman identifies in the case law is in any way attributable to an excessive focus on state as opposed to nonstate or nonterritorial interests. ${ }^{22}$ Indeed, if we look carefully at the cases discussed by Professor Berman, I'm not sure that we can even discern a pattern of parochialism, let alone recognize a problem that could be advanced by a pluralistic perspective.

In two out of the three cases discussed in the essay, Professor Berman concludes that the courts ultimately reached a defensible outcome in applying their own law. First, in the GlobalSanteFe $e^{23}$ case, Professor Berman discusses the court's conclusion that it was appropriate to apply U.S. law to a Korean defendant who registered a domain name for the specific purpose of extorting money from a U.S. corporation. ${ }^{24}$ One does not even have to abandon territorialism, let alone become cosmopolitan, to recognize that a forum state has a legitimate interest in providing a remedy for intentional extraterritorial wrongdoing targeted at a forum resident. ${ }^{25}$ As I have noted in the

MATION INFRASTRUCTURE 3, 12 (Brian Kahin \& Charles Nesson eds., 1997) (calling for new regulatory structures that better accommodate Internet transactions that are wholly unrelated to any particular physical location).

19 See Allan R. Stein, The Unexceptional Problem of Jurisdiction in Cyberspace, 32 INT'L LAW. 1167, 1171-73 (1998)

${ }^{20}$ Berman, supra note 5, at 1858 (quoting Kwame Anthony Appiah, Cosmopolitan Patriots, in Cosmopolitics: Thinking AND FeEling Beyond the NATion 91, 91 (Pheng Cheah \& Bruce Robbins eds., 1998)).

${ }^{21}$ Id. at 1860.

22 Professor Berman concedes this point. See id. at 1821 ("I leave to a future article the issue of how the insights of legal pluralism might inform conflict of laws.").

${ }^{23}$ GlobalSanteFe Corp. v. GlobalSantaFe.com, 250 F. Supp. 2d 610 (E.D. Va. 2003).

${ }^{24}$ See Berman, supra note 5, at 1826-29.

${ }^{25}$ See Restatement (FIRST) OF CONFLICT OF LAWS $§ 65$ (1934) ("If consequences of an act done in one state occur in another state, each state in which any event in the series of act and consequences occurs may exercise legislative jurisdiction to create rights or other interest as a result thereof."); RESTATEMENT (THIRD) OF THE FOREIGN RELATIONS LAW OF THE UNITED STATES $§ 402(1)$ (c) (1987) (authorizing a state to apply its law to cases involving "conduct outside its territory that has or is intended to have substantial effect within its territory"); see also Stein, supra note 16, at 445 (suggest- 
personal jurisdiction context, such targeted, intentional wrongdoing lends itself to extraterritorial regulation by the affected state without generating significant friction with the regulatory interests of other states. $^{26}$

Professor Berman may be right that the court's unarticulated assumption that U.S. law applies as an automatic consequence of the court having personal jurisdiction is a less persuasive rationale than the defendant's targeted wrongdoing in GlobalSantaFe. ${ }^{27}$ But the court could not have asserted subject matter jurisdiction unless there was some nexus with the United States in the first place: the Lanham Act provides for in rem jurisdiction only if "the domain name violates any right of the owner of a mark registered in the Patent and Trademark Office, or protected under subsection (a) or (c) of [the Act]. ${ }^{28}$ In order to fall within the Lanham Act, a mark must be used "in commerce," ${ }^{29}$ meaning that there must be some actual use of the mark in the U.S. market. ${ }^{30}$ A mark not used in the United States is not enforceable under the Act. ${ }^{31}$ In a case having no connection with the United States, the mere registration by a foreign defendant of a do-

ing a jurisdictional distinction between intentional cybersquatting and negligent trademark infringement).

${ }^{26}$ See Stein, supra note 16, at 421-22 (arguing that intentional tortfeasors "should reasonably anticipate being haled into court" in the affected state (quoting WorldWide Volkswagen Corp. v. Woodson, 444 U.S. 286, 297 (1980)).

${ }^{27}$ See Berman, supra note 5, at 1828 (" $[\mathrm{T}]$ he court seems to assume that the ACPA's legal reach is limited solely by the scope of the court's jurisdiction, not by any choice-of-law considerations.").

${ }^{28} 15$ U.S.C. $\$ 1125$ (d) (2) (A) (i) (2000).

${ }^{29}$ The "use in commerce" requirement is an express requirement for trademark registration, $i d$. $\S 1051$ (a)(1), and has been treated as an implied restriction on the protection of unregistered marks. See $4 \mathrm{~J}$. THOMAS MCCARTHY, MCCARTHY ON TRADEMARKS AND UNFAIR COMPETITION $§ 29: 2$, at 29-7 (4th ed. 2005) ("Priority of trademark rights in the United States depends solely upon priority of use in the United States, not on priority of use anwhere in the world."); accord Graeme B. Dinwoodie, Trademarks and Territory: Detaching Trademark Law from the Nation-State, 41 Hous. L. REV. 885,909 n.85 (2004).

${ }^{30}$ Buti v. Impressa Perosa, S.R.L., 139 F.3d 98, 105 (2d Cir. 1998) (finding that mere advertising in a U.S. market is not sufficient to constitute "use in commerce" for the purpose of the Lanham Act unless it is accompanied by any actual rendering of services in the United States). But see Int'l Bancorp v. Societe des Bains de Mer, 329 F.3d 359, 355-56 (4th Cir. 2003) (holding that the provision of services abroad to U.S. residents in conjunction with advertising in the United States constitutes "use in commerce" notwithstanding absence of services rendered in the United States), cert. denied, 124 S. Ct. 1052 (2004). See generally Dinwoodie, supra note 29, at 908-19 (discussing the "use in commerce" requirement).

${ }^{31}$ See Dinwoodie, supra note 29, at 909 ("Use of a mark in a foreign country creates no rights in the United States."). 
main name in Virginia could not provide the basis for in rem jurisdiction because the plaintiff would not be asserting the infringement of a mark protected under U.S. law. Moreover, a case for cybersquatting must be based on a "bad faith" registration, i.e., intentional harm toward the owner of a U.S. mark. ${ }^{32}$

Of course, not every decision protecting a U.S. mark will present as strong a case as does GlobalSanteFe for applying U.S. law and asserting in rem jurisdiction. GlobalSanteFe is a particularly strong case insofar as the plaintiff was a U.S. corporation, not merely the owner of a trademark protected under U.S. law. Moreover, the 2002 decision in Harrods Ltd. v. Sixty Internet Domain Names ${ }^{33}$ has the potential for creating mischief. ${ }^{34}$ In Harrods, the Court of Appeals for the Fourth Circuit held that the in rem provision could be applied to claims involving mere infringement rather than just being limited to "bad faith" cybersquatting. ${ }^{35}$ If and when courts use the in rem provision to assert jurisdiction and apply U.S. law where there has been no targeted infringement toward a mark used in the U.S. market, and no direct use of a U.S. name registrar, there may be a greater problem. ${ }^{36}$ But we are not there quite yet.

Similarly, in the Yahoo! case, the court of appeals ultimately decided that it had no jurisdiction to declare that the French litigants could not enforce their injunction against Yahoo! in the United States. ${ }^{37}$ Hardly parochial protectionism. But even focusing on the district court's grant of declaratory relief, I see the issue of enforcing foreign injunctions as more complicated than other recognition problems. Professor Berman faults the district court for equating the decision about whether enforcement of the judgment would violate the First Amendment with the question of whether the U.S. court could have constitutionally issued the underlying judgment. ${ }^{38}$ But his cri-

3215 U.S.C. $\$ 1125$ (d) (A) (i) (2000).

33 302 F.3d 214 (4th Cir. 2002).

${ }^{34}$ Unlike GlobalSanteFe, the defendant in Harrods directly availed itself of the Virginia registry. Id. at 221 .

${ }^{35} I d$. at 232.

${ }^{36}$ See, e.g., Catherine T. Struve \& R. Polk Wagner, Realspace Sovereigns in Cyberspace: Problems with the Anticybersquatting Consumer Protection Act, 17 BERKELEY TECH. L.J. 989, 1004 (2002) ("Whether or not the use of a U.S.-based dealer creates minimum contacts, it seems clear that the involvement of a U.S.-based administrator, without more, should not create the requisite contacts.").

${ }^{37}$ Yahoo! Inc. v. La Ligue Contre Le Racisme Et L’Antisémitisme, 379 F.3d 1120 (9th Cir. 2004), reh'g en banc granted, 399 F.3d 1010 (9th Cir. 2005).

${ }^{38}$ Berman, supra note 5, at 1837, 1879. 
tique does not take account of the type of judgment for which enforcement was sought. The district court was not merely being asked to deny recognition to a foreign judgment that it could not have constitutionally issued; the question was whether U.S. courts could help effectuate the French court's injunction of protected speech in the United States. ${ }^{39}$ That is surely more constitutionally problematic than enforcing a distasteful or even unconstitutional money judgment. The prospective impact of the French injunction makes an enforcing court more complicit in the underlying prior restraint of speech. ${ }^{40}$ Thus, even a "cosmopolitan" court finely attuned to the competing legal regimes applicable to the litigants' behavior would be appropriately concerned about betraying its domestic constitutional commitments in a case like this. Professor Berman concedes this in describing the decision as a "difficult case."

${ }^{39}$ The precise form of U.S. assistance-issuance of a U.S. injunction, or enforcement of monetary penalties-was never made clear in the case. The district court asserted that Yahoo! incurred daily monetary fines for its nonconformance with the French injunction. However, the court also noted that no fines had, in fact, been imposed by the French court, nor had the French plaintiff taken any steps to enforce the French judgment in the United States. 169 F. Supp. 2d 1181, 1188 (N.D. Cal. 2001), rev'd, 379 F.3d 1120 (9th Cir. 2004). Professor Reidenberg suggests that Yahoo! may not have even been in violation of the French order; the American courts may have misunderstood the scope of the French injunction as a consequence of a translation error. Reidenberg, supra note 3, at 1959.

${ }^{40}$ Whether or not this would constitute an unconstitutional "prior restraint" is complicated. "[A]dministrative and judicial orders forbidding certain communications when issued in advance of the time that such communications are to occur" are considered presumptively unconstitutional under the "prior restraint" doctrine. Alexander v. United States, 509 U.S. 544, 550 (1993) (internal quotation marks and emphasis omitted); see also Org. for a Better Austin v. Keefe, 402 U.S. 415, 419 (1971) (recognizing a "heavy presumption" against prior restraint on expression). But see Madsen v. Women's Health Ctr., Inc., 512 U.S. 753, 778-79 (1994) (Stevens, J., concurring in part) (asserting that "injunctive relief should be judged by a more lenient standard than legislation" because it is more narrowly tailored). Professsor Tribe has suggested that the problem with prior restraints is that the speaker may incur a penalty for disobeying the restraint without being given the opportunity to challenge the constitutionality of the restraint. See Laurence H. Tribe, American Constitutional LaW $\$$ 12-35 (2d ed. 1988); cf. Martin H. Redish, The Proper Role of the Prior Restraint Doctrine in First Amendment Theory, 70 VA. L. REV. 53, 97 (1984) (suggesting that injunctions issued after "a full and fair hearing by a competent judicial forum" raise fewer constitutional difficulties). The French injunction was issued following an adjudication on the merits, but that court did not evaluate whether or not the speech was protected under U.S. law. Any U.S. judicial enforcement of that injunction might therefore be considered an illegal prior restraint insofar as the speaker was not accorded a constitutional adjudication prior to incurring a penalty for violating the injunction.

${ }^{41}$ Berman, supra note 5, at 1878. 
Moreover, even putting aside the First Amendment implications, courts have traditionally been more cautious about recognizing foreign injunctions than about enforcing foreign money judgments, even in domestic cases. ${ }^{42}$ Even in a domestic context, it is was not clear until recently that the Full Faith and Credit Clause required states to give recognition to injunctions issued by sister states, and the scope of the enforcement obligation remains unclear. ${ }^{43}$ Enforcement of foreign injunctions is yet more problematic given the potential for imposing upon the enforcing court vastly divergent legal norms. The automatic issuance of a U.S. injunction as the means to enforce a foreign injunction would strain the notion that such equitable relief is discretionary, ${ }^{44}$ and the award of a fine for defendant's violation of a foreign injunction would strain the principle that foreign fines and penalties are not generally entitled to recognition. ${ }^{45}$ The uniquely problematic aspect of enforcing injunctions thus is recognized by the ALI Interna-

${ }^{42}$ Such recognition was not required under the First Restatement of Conflict of Laws, but was mandated in the Second Restatement. Compare RESTATEMENT (FIRST) OF CONFLICT OF LAWS $§ 449$ (2) (1934), with RESTATEMENT (SECOND) OF CONFLICT OF LAWS $\$ 102$ (1971).

${ }^{43}$ Baker v. Gen. Motors Corp., 522 U.S. 222, 223 (1998). In Baker, the Court held that while the Full Faith and Credit Clause requires enforcement of equity decrees, it did not require a Missouri court to exclude the testimony of a former General Motors employee who had been enjoined by a Michigan court from disclosing to third parties proprietary information about General Motors: "Full faith and credit, however, does not mean that enforcement measures must travel with the sister state judgment as preclusive effects do; such measures remain subject to the evenhanded control of forum law." Id. at 223-24.

${ }^{44}$ This was the primary rationale for denying the enforcement of sister-state injunctions under RESTATEMENT (FIRST) OF CONFLICT OF LAWS $\S 449 \mathrm{cmt}$. a (1934) ("Each court will decide for itself whether to leave the plaintiff to his ordinary remedy or to give him the extraordinary alternative relief.").

5 See Restatement (Third) of the Foreign Relations Law of the United STATES $§ 483$ (1987) ("Courts in the United States are not required to recognize or to enforce judgments for the collection of taxes, fines, or penalties rendered by the courts of other states."). Although the courts have gone out of their way to characterize foreign law as nonpenal for purposes of this provision, see, e.g., Desjardins Ducharme v. Hunnewell, 585 N.E.2d 321, 324 (Mass. 1992) (finding that an award of costs in a Canadian judgment did not constitute a "penalty"), the fines allegedly incurred by Yahoo! would seem to fall squarely within the scope of the provisions: "A penal judgment, for purposes of this section, is a judgment in favor of a foreign state or one of its subdivisions, and primarily punitive rather than compensatory in character. A judgment for a fine or penalty is within this section . . .." RESTATEMENT (THIRD) OF THE FOREIGN RELATIONS LAW OF THE UNITED STATES $§ 483 \mathrm{cmt}$. b; $c f$. American Law Institute, International Jurisdiction and Judgments Project, Tentative Draft No. 2, § 2(b) (i) (Apr. 13, 2004) (unpublished manuscript) ("Judgments for taxes, fines, and penalties may, but need not, be recognized and enforced."), available at http://www.ali.org/ali/ IJ\&J2004.pdf. 
tional Jurisdiction and Judgments Project, which makes foreign injunctions only contingently enforceable in the United States. ${ }^{46}$

Professor Berman's best case for demonstrating excessive parochialism is the Barcelona.com decision. ${ }^{47}$ This is the only case in which Professor Berman finds the application of U.S. law indefensible. But it is not clear how much the case really supports a charge of parochialism. At issue was the ownership of the "barcelona.com" domain name. The use of the name by Barcelona.com (Bcom) ${ }^{48}$ apparently violated Spanish, but not U.S., trademark law. Following an international arbitration in favor of the City of Barcelona pursuant to the resolution dispute policy of the Internet Corporation for Assigned Names and Numbers (ICANN), ${ }^{49}$ Bcom sought a declaration in the district court that "its use of the name [barcelona.com] does not infringe upon any trademark of defendant... [and] that [the City Council] is barred from instituting any action against [Bcom] for trademark infringement., ${ }^{, 50}$

Under Rule 4(k) of the ICANN Uniform Domain Name Dispute Resolution Policy (UDRP), the arbitration award for the city was automatically suspended upon the filing of any judicial proceeding in a court of competent jurisdiction. ${ }^{51}$ The suspension continues until the registrar receives:

(i) evidence satisfactory to us of a resolution between the parties; (ii) evidence satisfactory to us that your lawsuit has been dismissed or withdrawn; or (iii) a copy of an order from such court dismissing your lawsuit or ordering that you do not have the right to continue to use your domain name.

The court of appeals ruled in Bcom's favor on the basis that the Anticybersquatting Consumer Protection Act (ACPA) ${ }^{53}$ only provided

\footnotetext{
${ }^{46}$ American Law Institute, supra note 45, § 2(b) (ii) ("Declaratory judgments and injunctions or comparable orders are not directly enforceable, but may be entitled to recognition provided they meet the criteria of this Act.”).

${ }^{47}$ Barcelona.com, Inc. v. Excelentisimo Ayuntamiento de Barcelona, 330 F.3d 617 (4th Cir. 2003).

${ }^{48}$ The name was registered by the incorporators of Barcelona.com (Bcom). Bcom was then formed to commercially exploit the name. $330 \mathrm{~F} .3 \mathrm{~d}$ at 620 .

${ }^{49}$ Internet Corporation for Assigned Names and Numbers, Uniform Domain Name Dispute Resolution Policy, at http://www.icann.org/udrp/udrp-policy-24oct99. htm\#4 (last modified Feb. 5, 2002) [hereinafter UDRP].

${ }^{50}$ Barcelona.com, 330 F.3d at 621 (internal quotation marks omitted) (alterations in $\underset{51}{\operatorname{original} \text { ). }}$

${ }^{51}$ See id. at 626-27.

${ }^{52}$ UDRP, supra note 49.

${ }^{53}$ Pub. L. No. 106-13, div. B, § 1000 (a) (9), 113 Stat. 1501, 1536 (1999) (enacting
} 
remedies for the violation of U.S. trademark law, and Bcom, therefore, was entitled to a declaration that its registration of the barcelona.com domain name did not violate the Act. ${ }^{54}$ The case thus might be seen to support a charge of legal imperialism; unless Bcom's registration of the barcelona.com domain name violated U.S. law, the city could not force the transfer of the domain name pursuant to the arbitration order. As Professor Berman put it, the court "eschewed Spanish law and insisted on applying the ACPA. ${ }^{, 55}$

However, the peculiar procedural posture of the case may undermine that characterization. Contrary to Professor Berman's suggestion, it is not clear that the court privileged U.S. law over Spanish law. At issue here is the court's construction of the "reverse anticybersquatting" provision of the Lanham Act:

\begin{abstract}
A domain name registrant whose domain name has been suspended, disabled, or transferred [pursuant to a policy of a domain name registrar] may ... file a civil action to establish that the registration or use of the domain name by such registrant is not unlawful under this chapter. The court may grant injunctive relief to the domain name registrant, including the reactivation of the domain name or transfer of the domain name to the domain name registrant. ${ }^{56}$
\end{abstract}

In the domestic context, the provision operates simply as a hedge against possible legal errors inherent in the expedited, "adjudicationlite" context of ICANN arbitration. ${ }^{57}$ If the arbitration erroneously finds a trademark violation, the registrant can seek de novo judicial review under this section. ${ }^{58}$

The application of the provision to international disputes is more complex. What happens when the arbitration results in a transfer of a domain name not as a result of a mistaken interpretation of U.S. law, but because such a result is justified under foreign law? Does the provision require a court to reverse the arbitration on the premise that only justifiable basis for a transfer by the arbitrator is when the registration violates U.S. trademark law? Or is the provision limited in scope to correcting erroneous constructions of U.S. trademark law in the arbitration? Under the latter construction, a registrant might be

S. 1948, tit. 3, 106th Cong. (1999)) (codified in scattered sections of 15 \& 16 U.S.C. (2000))

${ }^{54}$ Barcelona.com, 330 F.3d at 629.

${ }_{55}^{55}$ Berman, supra note 5, at 1830.

${ }_{57}^{56} 15$ U.S.C. $\$ 1114(2)$ (D) (v) (2000).

${ }^{57}$ Barcelona.com, 330 F.3d at 624.

${ }^{58} I d$. at 626 . 
able to get a declaratory judgment that its registration did not violate the Lanham Act, but such a declaration would not immunize its registration from other attacks, including claimed violations of foreign law, and would not result in automatic vacation/injunction of the arbitration award.

Professor Berman's critique assumes the court adopted the former construction. $^{59}$ This reading is not without support in the opinion. The court does "reverse and remand" the district court's denial of declaratory relief to Bcom, and reverses its issuance of an injunction ordering the transfer of the domain name to the city. ${ }^{60}$ The court also notes the power of courts hearing ACPA claims to reverse arbitration decisions "grounded on principles foreign or hostile to American law." ${ }^{, 1}$ Moreover, it is clear from the decision that U.S. courts are without competence under the doctrine of "territoriality" to "entertain actions seeking to enforce trademark rights that exist only under foreign law. ${ }^{\text {} 62}$ Thus, the district court was without authority to affirmatively order the transfer of the domain name to the city pursuant to Spanish law. ${ }^{63}$ But that does not mean that the district court must now set aside the arbitration award simply because the registration was not in violation of the Lanham Act.

The key question, then, is what relief specifically Bcom is entitled to on remand under the appellate court's disposition. Must the arbitration be reversed and the transfer enjoined because the arbitration decision was not premised on any Lanham Act violation by Bcom (and therefore constitutes a decision "foreign or hostile to American law")? Or was the court simply indicating that Bcom was entitled to a declaration that its registration was not in violation of the Lanham Act (but the arbitration may be sustained because the registration was in violation of other law)? The former construction would support Professor Berman's charge of parochialism; the latter would not.

A middle ground may be that the city cannot obtain a transfer of the domain name unless and until some national court confirms the

${ }^{59}$ Cf. Laurence R. Helfer, Whither the UDRP: Autonomous, Americanized, or Cosmopolitan?, 12 CARDOZO J. INT'L \& COMP. L. 493, 498 (2004) (“[U]nless foreign mark owners can also demonstrate trademark rights under U.S. law, nothing will prevent registrants from proving that their use of the domain name embodying a foreign mark was lawful under the Lanham Act.").

${ }^{60}$ Barcelona.com, 330 F.3d at 629.

${ }^{61} I d$. at 626.

${ }^{62} I d$. at 628 .

${ }^{63}$ The court did not have to reach this issue, since the parties agreed that the city did not, in fact, assert any counterclaims for injunction. Id. at 629. 
conclusion of the arbitration that Bcom's registration in fact violated the city's rights under Spanish law. This would be a consequence not of the ACPA per se, but of the ICANN arbitration policy. Under Rule $4(\mathrm{k})$ of the URDP, the registrar held the arbitration award in suspension pending judicial resolution of the parties' dispute. It may well be that ICANN would read even a mere declaratory judgment for Bcom to mean that there has either been no judicial resolution, or that there has been a judicial resolution in Bcom's favor. In either event, the arbitration award would never be implemented. However, such an outcome would not preclude the city from establishing a violation of Spanish law in a Spanish court. The ACPA would not insulate Bcom from the duty to transfer the domain name if enforcement of the Spanish judgment were sought in the United States, although there would be some interesting res judicata questions for an enforcing court to sort out. ${ }^{64}$ Note that even in this middle ground, the "hegemonic" effect of U.S. law would be a consequence not of the ACPA, but of ICANN's own policy.

The Barcelona.com case thus lends itself to a range of interpretations with differing implications for Professor Berman's thesis. Professor Berman may have the right construction, but I would like to reserve judgment until we see a less ambiguous case.

In conclusion, none of the three cases that Professor Berman focuses on clearly demonstrates a trend toward parochialism. All three end up applying U.S. law, but for defensible, nonparochial reasons. Moreover, the sources of non-U.S. legal authority to which Berman suggests the courts look in these cases were exclusively stategenerated, territorially based legal rules. Legal pluralism is doing no work here.

None of this detracts from my enormous admiration for Professor Berman. He is unquestionably one of the most provocative, deep thinkers in the conflicts/cyberlaw field today. I am just not sure that

${ }^{64}$ Even if the U.S. enforcing court were to look to U.S. rather than Spanish preclusion law, the ACPA judgment would not necessarily preclude enforcement of the Spanish judgment in this scenario to the extent that a judgment does not typically bar claims that could not have been asserted in the initial proceeding. See RESTATEMENT (SECOND) OF JUDGMENTS $§ 26(1)$ (c) (1982) (noting that a claim is not barred when it could not have been brought in the initial proceeding due to jurisdictional limitations); see also Marrese v. Am. Acad. of Orthopaedic Surgeons, 470 U.S. 373, 382 (1985) ("[C]laim preclusion generally does not apply where ' $[\mathrm{t}]$ he plaintiff was unable to rely on a certain theory of the case or to seek a certain remedy [. . .] because of the limitations on the subject matter jurisdiction of the courts...." (quoting RESTATEMENT (SECOND) OF JUDGMENTS § 26(1) (c) (second alteration in original)). 
[Vol. 153: 2003

the problem is as bad as he suggests, or that adopting a "cosmopolitanism vision" gives us any greater insight into these complex choiceof-law problems. 